\title{
患者所持型情報共有ツール『わたしのカルテ』の評価： OPTIM-study
}

\author{
森田 達也 ${ }^{1)}$, 古村 和恵 $^{2)}$, 佐久間由美 ${ }^{3)}$, 井村 千鶴 ${ }^{4)}$, 野末よし子 ${ }^{4)}$, \\ 木下 寛也 ${ }^{5)}$, 白髭 \\ 豊6), 山岸 暁美7), 鈴木 \\ 聡 ${ }^{8)}$
}

\begin{abstract}
1) 聖隷三方原病院 緩和支持治療科, 2) 大阪大学大学院 人間科学研究科 臨床死生学・老年行動学研究分野, 3) 聖 隷三方原病院 看護部, 4) 聖隷三方原病院 浜松がんサポートセンター, 5) 国立がん研究センター東病院 緩和医療

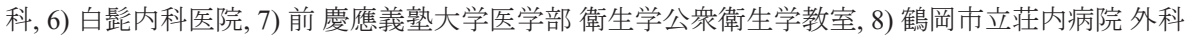

受付日 2012 年 5 月 7 日 / 受理日 2012 年 5 月 28 日

\begin{abstract}
本研究の目的は, 患者所持型情報共有ツール『わたしのカルテ』の利用状況を明らかにすることである. 配布数, 医師 706 名・看護師 2,236 名の質問紙調査, 医療福祉従事者 40 名に対するインタビュ一調査, 事例を分析した. 年間平均 1,131 冊が配布され, 15\%の医師, 16\%の看護師が使用した. 医療者の体験としては, 現状として【一部では使われているが全体 には広がらない】, 効果として【患者の自己コントロール感が上がる】【医療福祉従事者間の情報共有になる】, 普及しない 理由として【患者にとって利益がない・負担が大きい】【関係する地域の職種すべてが使用する必要がある】ことが挙げら れた. 11 病院で運用が試みられたが, 3 年間継続した運用ができたのは 2 病院のみであった. わが国の多くの地域において, 患者所持型情報共有ツールを短期間に地域全体に普及させることの実施可能性は低いことが示唆された。

Palliat Care Res 2012; 7(2): 382-8
\end{abstract}

Key words: 緩和ヶア, 地域, 患者所持型情報共有ツール

\section{緒 言}

地域全体でのがん緩和ケアの普及のために, 患者情報の共有 が求められている ${ }^{1,2)}$. 地域で利用できる電子カルテなどの情 報共有手段のある地域以外では, 紙媒体の患者所持型情報共有 ツールはその 1 つである.『お薬手帳』はおもに薬剤について の情報を共有するための手段であるが, 薬剤以外の患者の病 状, 病歷, 緊急時の対応などの患者情報を共有する手段として, 紙媒体の患者所持型情報共有ツールの利用が国内外でしばし ば行われている ${ }^{3-13)}$. 患者所持型の情報共有ツールは, 情報を 自分で管理したいという患者には医療者が積極的に関与寸る ならば自己コントロール感が改善するなどの効果がみられる. しかし, 情報共有という観点からは, 患者自身が希望しないこ と, 地域全体の医療関係者に運用を周知寸ることは困難である ことが示唆されている ${ }^{3)}$.

本研究の目的は, 地域緩和ケアプログラムで作成された地域 で統一した患者所持型情報共有ツール『わたしのカルテ』の 使用経験を記述することにより, 地域で患者情報を共有するた めのツールについての洞察を得ることである.

\section{対象・方法}

本研究は, OPTIM プロジェクト (Outreach Palliative care Trial of Integrated regional Model, 厚生労働科学研究費補助金第 3 次
対がん総合戦略研究事業「緩和ケアプログラムによる地域介 入研究」)の一部として行われたものである ${ }^{14,15)}$. OPTIM プロ ジェクトは, 4 地域を対象とした地域介入による前後比較研究 である.介入地域として, 鶴岡地域, 柏地域, 浜松地域, 長崎地域 が対象となった.

地域に対する介入として, (1)緩和ケアの標準化と継続性の向 上, (2)患者・家族に対寸る適切な知識の提供, (3)緩和ケア専門 家による診療, (4)地域の緩和ケアの包括的なコーディネーショ ンと連携の促進を柱とする複合介入, が行われた.

\section{患者所持型情報ツール}

「地域の緩和ケアの包括的なコーディネーションと連携の促 進」のための介入の一部として,『わたしのカルテ』が地域内 での患者情報の共有と患者自身の自己コントロール感の向上 の目的として作成された. 内容は, (1)基本的な患者情報 (病名, 病状, かかっている医療機関など), (2)患者の意向 (大切にして いること, 病状説明・療養場所の希望, 心肺蘇生の希望など), (3)診療記録, の 3 部構成とした. 大きさについては, 小さいもの にする意見と資料を挟めるようにする意見の両方があったが, 資料を挟めるように A4 判とした。

各地域の研究責任者が, 参加施設で運用を促した。

\footnotetext{
Corresponding author: 森田達也 聖隷三方原病院 緩和支持治療科

干 433-8558 静岡県浜松市北区三方原町 3453

TEL 053-436-1251 FAX 053-438-2971 E-mail: tmorita@sis.seirei.or.jp
} 


\section{評価・解析}

本研究では 3 つのデータを利用した. 詳細は他の論文に記載 した ${ }^{16,17)}$.

\section{1 配布数と医師・看護師の利用頻度}

利用の指標として, 地域への配布数の 3 年間の合計值を集計 した. また, 4 地域の病院, 診療所, 訪問看護ステーションに勤 務するがん診療に携わる医師, 看護師を対象として質問紙調査 を行い,『わたしのカルテ』を「見たことがない」「見たことは あるが使っていない」「使用した」に対する回答を集計した。

\section{2 インタビュー調査}

各地域において介入の運営, 立案や実施に関わったもの(コ アリンクスタッフ) 全員を対象としてインタビュー調查を行っ た. 用いられたおもな質問は, 「介入で使用されたツールで役に 立った・立たなかったものはありますか. それはどうしてです か」であった。

内容分析の技法にしたがって, 逐語録化したテキストから, 『わたしのカルテ』に関する体験・評価とその理由を表現して いる部分を意味単位として抽出しコードをつけ, 意味内容の類 似性・相違性からカテゴリーを形成し, 頻度を算出した ${ }^{18)}$. 分 析は緩和ケア医師と看護師 1 名が独立して行い, もう 1 名の看 護師を含めた 3 名で議論して一致させた.

以下,カテゴリーを【】,データ (発言)を［］で示す．

\section{3 事例研究}

『わたしのカルテ』を運用したすべての病院から, 経過の記 述を文章で取得した. 鶴岡地域では 1 病院の限定した診療科で, 浜松地域では 1 病院の限定した診療科と 1 病院の寸べての診 療科で断続して運用した。

そのうち, 1 施設の事例を記述した。

\section{結 果}

\section{1 配布数と医師・看護師の利用頻度}

3 年間での配布数は, 延べ 13,574 冊 (鶴岡地域 2,350 冊, 柏地 域 3,339 冊, 浜松地域 6,634 冊, 長崎地域 1,251 冊), 年間各地域 平均 1,131 冊 (死亡がん患者数は 1,387 名) であった.

質問紙調查は医師 1,763 名, 看護師 3,156 名が対象となり, それぞれ, 846 名 (48\%), 2,609名 $(83 \%)$ から回答を得た. 医師 706 名, 看護師 2,236 名が有効回答であった. 医師では, 「使用 した」 $14 \%(\mathrm{n}=96)$,「見たことがある」37\% ( $=255)$,「見た ことがない」49\% (n=336) であった. 看護師では,「使用した」 $16 \%(n=345)$,「見たことがある」33\% ( $=728)$,「見たことが ない」 $51 \%(\mathrm{n}=1,119)$ であった.

\section{2 インタビュー調査}

103 名が対象となり, 全員が承諾したが 2 名は予定が合わ ないなど実際上の理由で実施できなかったため, 101 名で調 査が終了した. 録音時間は $135 \pm 39$ 分であった. 該当する回 答のあったものは 40 名であった (鶴岡 6 名, 柏 15 名, 浜松 13 名, 長崎 6 名; 病院・訪問・診療所看護師 19 名, 病院・診療所 医師 7 名, 病院 - 保険薬局薬剤師 5 名, 介護支援専門員 - 医療
ソーシャルワーカー・事務職・栄養士 9 名).

使用経験に関する発言はほとんどが浜松地域のものであ り,他の 3 地域では「あまり使用しなかった」ことが述べられ た. 語られた内容は, 現状として【一部では使われているが全 体には広がらない】, 効果として【患者とのコミュニケーショ ンのきっかけとなる】【患者の自己コントロール感が上がる】 【医療福祉従事者間の情報共有になる】, 普及しない理由とし て【患者にとって利益がない・負担が大きい】【関係する地域 の職種すべてが使用する必要がある】【既存の類似のものがあ る】ことであった (表 1).

要約すると, 自らの情報を整理して知ろうとする一部の患者 では有用で, 患者の自己コントロール感が向上し, 医療福祉従 事者間の情報共有も進む. しかし, 多くの患者では, 実感でき る利益がなく, 記入や記録を整理する作業そのものが負担とな ることや, 1 施設だけで取り組んでも他の施設で使用した時に 意義が知られていないと使う意欲がなくなること,『お薬手帳』 や各施設ですでに存在するノートや電子カルテなどがあるた め普及しないことが語られた。

\section{3 事例研究}

4 地域のうち少なくとも 11 病院で『わたしのカルテ』の運 用が試みられたが, 9 病院では 3 年間継続した運用ができな かった. その理由は, 対象者が広範囲にわたるため関係者で統 一した運用ができない(患者が見せても医療関係者が知らな いことが起きる, 書いたものをフォローする時間がない), 患者 自身が記入や管理を望まない, 地域の電子カルテなど他のツー ルがあるので情報共有の目的では必要ない,がん患者に限定し て運用できない,などであった。

3 年間を通しての運用が可能であった 2 病院のうち 1 病院 の事例を示寸.この病院では, 最初に, 関係者でのフォーカスグ ループを行い, (1)外来通院中の病院と保険薬局間での抗がん治 療についての情報, (2)病院から在宅療養になる時の病院と地域 医療福祉従事者間での患者の病状 (生じうる変化とその対応) と自宅に帰ってからの生活の情報, (3)在宅療養中の地域医療福 祉従事者間での患者の病状・希望の情報, を共有することを目 的とした. 具体的には, (1)については, 入院患者が説明を受けた 抗がん治療の治療説明書を医師または看護師が挟んで患者に 保険薬局に持っていくことを依頼する, (2)については, 退院支 援・調整プログラムの一環として, 抗がん治療の治療説明書, 退院時に患者に渡す退院シート (生じうる变化とその対応, 連 絡先などが記載されたもの), 入院中の看護計画書を病棟看護 師が挟んで患者に渡す, (3)については, 患者の自宅に『わたし のカルテ』を置いて, 地域医療福祉従事者が書き込むことを行 うように㗢きかけた。

運用は思うように進まなかったため, 患者, 病院医師・看護 師, 診療所医師 - 看護師, 訪問看護師, 病院薬剤師 - 保険薬局薬 剤師にヒアリングを行ったところ, 患者からは「(薬局に) 持っ て行ったが知らないようだった, 薬の説明は希望しない, 病名 を薬剤師に知られたくない, 保険薬局薬剤師からは「がん患 者かどうか分からないのに声をかけるのがためらわれる. 説明 を希望しない患者がいる」, 訪問看護師からは「『わたしのカル テ』に情報が挟まっていることを知らなかった」, 診療所医師・ 看護師からは「本当に共有したい情報は, 患者の読めるところ には書けないことが多い. 情報共有のために診療記録と別に記 
表 1 『わたしのカルテ』の評価

\begin{tabular}{l} 
1. 現 状 \\
\hline 【一部では使われているが全体には広がらない】 \\
[すごく活用してる人と, そうじゃない人の差が大きい. 繰り返しの人が毎回持ってくる \\
かというとそうでもなくて. 抗がん剂治療をやっている患者さんは, 検査データとかお薬の \\
説明の用紙とかすごくいっばい入れて活用している方もいるんですよ.『わたしのカルテ』 \\
持ってるからこれに挟んでとか, 穴を開けてとか. でも, 自分でファイルを作る患者さんも $]$ \\
(浜松地域, 緩和ケアチーム看護師)
\end{tabular}

2. 効 果

【患者とのコミュニケーションのきっかけとなる】

[しっかり書いてくださってる方は，つらい話でも聞きたいですとか書いてくれてそれ で話を広げるきっかけになる. 私が役に立ったって思ったのは, 1 回退院してまたちょっと 入ってまた退院になった時, あれがあると一緒に振り返るには本当に良くて, 家で困らな かったとか聞き返せたので, 本当にあそこに綴じてて一緒に見れて良かった）(浜松地域, 病院看護師)

【患者の自己コントロール感が上がる】

[検査データとか諸々も全部入れてもらって, 自分で採血データを気にされる方は本当に 多くて, 私たちが忘れてると,「コピーしてきてちょうだい」って言われる方がほとんど, 本 当に多かった. その方々はデータを見て, 前はこれで良くなったとか私たちに説明できるぐ らいの方もいっぱいみえて, データが比べられたりとかしていい] (浜松地域, 病院看護師)

【医療福祉従事者間の情報共有になる】

[どんな質問したとか, お薬をお渡ししたとか, 患者さまの検査結果とかですね, そういう ものが 1 つにまとめられていることで, 過去にどういうことをしたとまとめられて分かる のがまず良いことと. 緊急の時, 先生とか看護師さんがどのように説明しているか, 説明内 容も 1 つにまとめられているので対応しやすい. 保険薬局は処方せんの内容しか患者さま の情報を得ることがなかなかできないので. たとえば, 退院された時にどういう説明をされ ているかを詳しく, 何か治療方針の変化があった時どのように説明されているかがまとま るので, そうすると先生の考えが分かるので対応しやすい] (浜松地域, 保険薬局薬剂師)

[状態が分かる, その時の状態が分かるので把握しやすいといいますか, その時の状況が 分かる. 先生の方もこういうことがあるんですか, 個人的な自転車の運転を中止しましたと かコメントも残してあったり, こういうことを言ってきましたみたいなのがある）(鶴岡地 域, 訪問看護師)

3. 普及しない理由

【患者にとって利益がない・負担が大きい】

[記録をするのもなかなかご本人がするのが面倒という人とかいるので, 訪問へ行ってる 時は, ほとんど今日の状況を書いて, 家族の方に見てもらって, それからデイケアに行く時 はそれを持ってって, デイケアの人が書いて, 診察の時は先生がそれを書いてとかっていう ふうに（鶴岡地域, 訪問看護師)

【関係する地域の職種すべてが使用する必要がある】

[患者さんっていっぱいもらいますよね.これ以外にもいっぱい. 本当にその場で説明し てても (意義を理解することは 1 度では) 難しくて. 持っていくっていうことの認識がなか なかもてない. 地域の薬局さんがどこでも対応してくれているわけではなかったので, そう すると, これを持ってって, これは何ですかってなりかねないんで. よっぽど診察で先生が 「これに書いときましょうね. 薬局でも見せてくださいね」とこれを見て説明して, 薬局で もこれを見て説明するっていう(ことがないと普及するのは難しかったと思う)（浜松地域, 病院薬剂師)

【既存の類似のものがある】

[いろんな手帳が多すぎなんですよ. 健康手帳みたいなのもあり,『お薬手帳』を今はがん ばっていっぱい多いんです. 本当は何か総合的なものが 1 個あればいいんでしょう, 全部の 職種が張れるような. どっかで国とかでまとめて, 本当は何か 1 個あればいいのかと思うん ですけど.『お薬手帳』も何冊も持ってこられる方がいて（柏地域, 病院薬剂師) 
録をつくる時間がない」との意見が出された.

以上の経験から, 運用を改善した. (1)外来通院中の病院と保 険薬局間での情報共有については, 地域に存在するすべての保 険薬局で統一した運用を行うことの難しさ, 患者が保険薬局と 情報を共有することに意義を感じない場合も多いことから, 運 用を中止して『お薬手帳』での情報共有が試みられた. (3)在宅 療養中の地域医療福祉従事者間での情報共有については, 本当 に共有したい情報は患者や家族が見られるものには記入でき ないこと, 地域医療者の時間のなさから, 運用を中止して電話 やメールでの情報共有が図られた.一方, (2)病院から在宅療養 になる時の病院と地域医療福祉従事者間での情報共有につい ては, 腫瘍センターへの入院ごとに看護師が『わたしのカル テ』をあずかり検查所見や看護計画を綴じていくこと, 患者に 渡した情報が『わたしのカルテ』に挟まれていることを在宅 医療の関係者に繰り返して案内することにより運用が継続さ れた。

\section{考察}

本研究は, OPTIM プロジェクトで作成した『わたしのカル テ』の評価に関する副次的研究である.患者からみた評価につ いては,がん患者 50 名を対象とした研究により, 情報を管理す ることで治療内容の理解が深まり, 医療者や家族・他の患者と のコミュニケーションも改善することがある一方で, 記入自体 を好まない患者や, 地域全体の医療関係者に運用を周知するこ とが非常に難しいことが示された ${ }^{19)}$.これらは, 国際的にも同 じ知見であり ${ }^{3-9)}$, 患者所持型情報共有ツールが運用されるた めには医療者側の関心と努力が必要であるとする国内の観察 とも一致する ${ }^{12}$. 本研究の知見もこれらを医療福祉従事者の視 点から支持するものである. すなわち, 患者所持型の情報共有 ツールを広範囲に情報共有の目的で使用した場合には, 一部の 患者には有益であるが, 少なくとも短期間に地域全体に普及さ せるのは困難であると考えられる.

患者所持型情報共有ツールの運用を考える場合に最も重要 であることは, 患者自身が利益を感じない運用方法は継続しな いことである. 患者が情報を知ることで病状についてよく知 り, より納得のいく意思決定ができるなど患者にとって有用だ と感じられる支援が提供されなければ, 医療者間の情報共有の ために患者が「情報を持って歩く」ことは期待できないと考

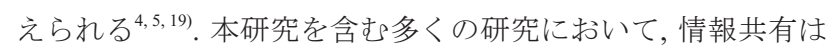
医療者にとっては重要な「効果」の1つであるが, 患者にとっ ては実感できる意義が少ないため, 関係する地域全体の医療福 祉従事者の積極的な関与がなければ普及は難しいことが示唆 されている ${ }^{3-9,19)}$. しかし, 現実的に, がん患者に関係する地域 全体の寸心゙ての職種, すべての施設の医療福祉従事者が積極的 な関与をすることは小規模な地域を除くと期待しにくいため, 患者所持型情報共有ツールの全国的な普及は現状では難しい と考えられる.

現在の枠組みを超えた情報共有としては, 疾患ごと・行政機 関ごとに分かれている『健康手帳』や『お薬手帳』など複数 の既存のツールを全国で 1 つまとめる, あるいは地域単位で の電子カルテを導入するという方法がある.

現在のところ, 実施可能な地域での情報共有のあり方とし て, 本研究からは, いつ, 誰と, 何の情報を共有することを改善
するのかをまず明確にすることの重要性が示唆される. 本研究 の対象地域では, (1)外来通院中の病院と保険薬局間での抗がん 治療についての情報, (2)病院から在宅療養になる時の病院と地 域医療福祉従事者間での患者の病状・生じうる変化とその対 応, (3)在宅療養中の地域医療福祉従事者間での患者の病状・希 望の情報, が主要な情報共有の問題であった.

地域全体に電子カルテを整備する方法以外の既存の手段で これらを解決するならば, 3 つを分けて考える必要がある.す なわち, 外来通院中の病院と保険薬局間での抗がん治療につい ての情報については, 既存の『お薬手帳』があり, 必要な情報 が比較的限られているため, 新しい手段を用いるのではなく, 『お薬手帳』に病名や治療に関寸る情報を記載するなどの方法 で対応することが有用と考えられる ${ }^{10,11)}$. 病院から在宅療養に 移行寸る時の病院と地域医療福祉従事者間での情報共有につ いては, 福祉職を含めて, 患者に関わる関係者が多くなること から, 患者が見ることのできる情報 (患者に渡したもの) を『わ たしのカルテ』などのファイル機能のあるものに一括して集 約しておき関係者が見られるようにしておくとともに, 患者に 伏せる内容についてはカンファレンスや紹介状などでやりと りすることが適切であると考えられる. 在宅療養中の地域医療 福祉従事者間での情報共有については, 紙媒体ではタイムリー な情報共有や患者に伏せる情報を共有できないため, 電話や メール (患者ごとのメーリングリストなど) の利用が有用と考 えられる ${ }^{20,21)}$.

本研究の限界として, 短期間の研究であり長期的な評価はで きないこと, 包括的介入の一部として行ったため地域全体への 介入の程度が弱いことがある。

以上より,がん緩和ケア領域において, 地域全体での患者の 情報を共有することを目的として患者所持型情報共有ツール を短期間に地域全体に普及させることの実施可能性は低いと 考えられる.いつ, 誰が, どのような情報を共有する必要がある かの観点から各地域で可能な情報共有手段を最大限とること が必要であり, 現時点では, 刻々と変わる患者の状況に応じて 臨機応変な対応を可能に寸るネットワーク構築に労力を費や す方が有用なのかもしれない22).

謝辞 本研究は, 厚生労働科学研究費補助金第 3 次対がん 総合戦略研究事業「緩和ケアプログラムによる地域介入研究」 の助成を受けた.

\section{文 献}

1) 井村千鶴, 古村和恵, 末田千恵, 他. 地域における緩和ケア の連携を促進する取り組み一フォーカスグループの有用 性3. 緩和ケア 2010; 20: 417-22.

2) 山岸暁美, 森田達也, 古村和恵, 他. 地域のがん緩和ケアの 課題と解決策の抽出一OPTIM-Study による複数地域・多 職種による評価. 癌と化学療法 2011; 38: 1889-95.

3) Gysels M, Richardson A, Higginson IJ. Does the patient-held record improve continuity and related outcomes in cancer care: a systematic review. Health Expect 2007; 10: 75-91.

4) Ko H, Turner T, Jones C, et al. Patient-held medical records for patients with chronic disease: a systematic review. Qual Saf Health Care 2010; 19: e41.

5) Finlay IG, Wyatt P. Randomised cross-over study of patient-held 
records in oncology and palliative care. Lancet 1999; 353: 558-9.

6) Drury M, Yudkin P, Harcourt J, et al. Patients with cancer holding their own records: a randomised controlled trial. Br J Gen Pract 2000; 50: 105-10.

7) Cornbleet MA, Campbell P, Murray S, et al. Patient-held records in cancer and palliative care: a randomized, prospective trial. Palliat Med 2002; 16: 205-12.

8) Lecouturier J, Crack L, Mannix K, et al. Evaluation of a patientheld record for patients with cancer. Eur J Cancer Care (Engl) 2002; 11: 114-21.

9) Williams JG, Cheung WY, Chetwynd N, et al. Pragmatic randomised trial to evaluate the use of patient held records for the continuing care of patients with cancer. Qual Health Care 2001; 10: $159-65$.

10) 照井一史, 佐藤淳也, 玉田麻利子, 他. 外来がん化学療法に おける薬・薬連携構築に向けた実態調査と取り組み. 日病 薬師会誌 2008; 44: 424-7.

11) 松久哲章, 江口久恵. 病院・保険薬局間で患者情報を共有 化する.薬局 2010; 61: 3378-84.

12)坂出市立病院ホームページ〔http://www.city.sakaide.lg.jp/ site/sakaide-hospital/]

13) 国立がん研究センターホームページ〔http://www.ncc.go.jp/ $\mathrm{jp} /]$

14) Yamagishi A, Morita T, Miyashita M, et al. Palliative care in Japan: current status and a nationwide challenge to improve palliative care by the Cancer Control Act and the Outreach Palliative Care Trial of Integrated Regional Model (OPTIM) study. Am J Hosp Palliat Care 2008; 25: 412-8.
15) Morita T, Miyashita M, Yamagishi A, et al. A region-based palliative care intervention trial using the mixed-method approach: Japan OPTIM study. BMC Palliat Care 2012; 11: 2 .

16) 森田達也, 野末よし子, 花田芙蓉子, 他. 地域対象の緩和 ケアプログラムによる医療福祉従事者の自覚する変化： OPTIM-study. Palliat Care Res 2012; 7: 121-35.

17) 森田達也, 井村千鶴, 野末よし子, 他. 地域緩和ケアプログ ラムに参加した医療福祉従事者が地域連携のために同職 種・他職種に勧めること. Palliat Care Res 2012; 7: 163-71.

18) Krippendorff K. Content Analysis: An Introduction to Its Methodology. Sage Publications, Beverly Hills, 1980. (三上俊 治, 椎野信雄, 橋元良明 訳. メッセージ分析の技法一「内容 分析」への招待. 勁草書房, 東京, 1989)

19) Komura K, Yamagishi A, Akizuki N, et al. Patient-perceived usefulness and practical obstacles of patient-held records for cancer patients in Japan: OPTIM study. Palliat Med 2011 Dec 16. [Epub ahead of Print]

20) 白髭 豊. 長崎在宅 Dr. ネットの取り組みと「緩和ケア普 及のための地域プロジェクト」. 片山壽 監著. 地域で支え る患者本位の在宅緩和ケア. 篠原出版新社, 東京, 2008; 17288.

21) 中野一司. 地域連携ネットワーク型在宅医療システムをつ くりあげるために一在宅医療の 3 ワークを通して. 訪問看 と介護 2008; 13: 980-5.

22) 森田達也, 野末よし子, 井村千鶴. 地域緩和ケアにおける 「顔の見える関係」とは何か? Palliat Care Res 2012; 7: 323-33.

著者の申告すべき利益相反なし 


\title{
Short Communications
}

\section{Usefulness and perceived-barriers of patient-held- records in palliative care settings: the OPTIM-study}

\author{
Tatsuya Morita ${ }^{1)}$, Kazue Komura ${ }^{2)}$, Yumi Sakuma ${ }^{3)}$, \\ Chizuru Imura ${ }^{4)}$, Yoshiko Nozue ${ }^{4)}$, Hiroya Kinoshita ${ }^{5)}$, \\ Yutaka Shirahige ${ }^{6)}$, Akemi Yamagishi ${ }^{7)}$ and Satoshi Suzuki ${ }^{8)}$
}

\begin{abstract}
1) Department of Palliative and Supportive Care, Seirei Mikatahara General Hospital, 2) Department of Clinical Thanatology and Geriatric Behavioral Science, Graduate School of Human Sciences, Osaka University, 3) Division of Nursing, Seirei Mikatahara General Hospital, 4) Hamamatsu Cancer Support Center, Seirei Mikatahara General Hospital, 5) Department of Palliative Medicine, National Cancer Center Hospital, East, 6) Shirahige Clinic, 7) Department of Preventive Medicine and Public Health, School of Medicine, Keio University, 8) Department of Surgery, Tsuruoka Municipal Shonai Hospital
\end{abstract}

\begin{abstract}
The primary aim of this study was to describe how patient-held-records was used in the regional palliative care program (OPTIM-study). The number of patient-held-records disseminated was 1,131 per region per year. A total of 15\% and $16 \%$ of 706 physicians and 2,236 nurses in the region reported that they used patient-held-records disseminated during the study periods, respectively. In-depth interview identified themes [difficulty in dissemination], potential benefits of patient-held-records ([improved sense-of-control of patients], [improved information sharing among health care professionals]), and barriers ([lack of patient-perceived benefits and patient burden], [necessity that all health care professionals involved should be aware the value of patient-held-records and understand how to use it]). Of 11 hospitals who introduced patient-held-records, only 2 hospitals continued to use it during 3-year study periods. In conclusion, region-wide dissemination of patient-held-records seems to be unfeasible in many regions in Japan. Palliat Care Res 2012; 7(2): 382-8
\end{abstract}

Key words: palliative care, region, patient-held-record 
Table 1 Descriptions about patient-held-records

1. Current status
[The notebook is used by some patients, but not widely]
"Some patients thoroughly utilize the material, and others do not use it at all. Patients who attend hospital frequently
do not necessarily bring it each time. A patient undergoing anticancer drug treatment keeps various documents,
including the results of examinations and descriptions of drugs, bound in the notebook 'My Medical Chart'. Another
patient punches holes in those documents and puts them in their original file." (Hamamatsu area, nurse in a palliative
care team)

2. Advantages

[The material promotes communication with patients]

"It is easy for us to communicate with patients who utilize the notebook and write down comments in it frequently. They say, 'I would like to hear any information on my condition from you'. The notebook was also useful when an inpatient was discharged, then readmitted, and discharged recently. I was able to ask the patient about his/her conditions during the period of the first discharge while viewing copies of medical records attached to the notebook." (Hamamatsu area, hospital nurse)

[The material helps patients know that they have learned self-control]

"A large number of patients are always concerned about their blood sampling and other examination data, and want the notebook to include all kinds of health care records. Some patients even ask us: 'Can I have a copy of the test results?' before we provide them with the document. The material helps them check and compare the data to understand their conditions." (Hamamatsu area, hospital nurse)

[The notebook allows health and welfare care professionals to share information]

"One of the advantages of the notebook is that it provides all kinds of information, including questions to a patient, drugs administered, examination results, and other records. It allows us to respond to an emergency case promptly since explanations provided by physicians and nurses for each hospital visit are on the same page. Usually, health insurance-based pharmacies like us cannot obtain patient information other than prescriptions. By reading explanations and instructions that a patient received at discharge or when the treatment course was changed, we can understand the therapeutic strategy developed by the attending physician for the patient." (Hamamatsu area, pharmacist at an insurance-based pharmacy)

"The material allows me to understand the conditions of patients and their situation. It also helps physicians notice what otherwise might be overlooked. Physicians often write down comments, including 'I told a patient not to ride a bicycle', and requests by patients." (Tsuruoka area, home-visiting nurse)

3. Obstacles to its widespread use

[Few advantages for patients/Burden of filling in the notebook]

"Some people do not bother to fill in the notebook. When I visit one of those patients as a home-visiting nurse, I record the patient's condition on that day in the notebook, and show it to his/her family. The patient brings the notebook to the day care center to have a staff member fill it in, and, in hospital, physicians write down their diagnosis in it." (Tsuruoka area, home-visiting nurse)

[There is no point in using the material unless it is used by all health-related organizations in the community]

"As patients receive a variety of documents besides this in hospital, it is difficult for us to explain to them the significance of the material and taking it to a pharmacy and other health professionals. Since some local pharmacies do not know of the material, a patient who brings and shows it to one of them might be asked: 'What is this?' To increase awareness of this notebook among patients, a physician has to provide a patient with a clear explanation while giving a diagnosis: 'I am going to write down the results in this notebook of yours. Show it to a pharmacist', to help the patient convey its purpose to a pharmacist at a local pharmacy." (Hamamatsu area, hospital pharmacist)

[There are already a lot of similar materials]

"Too many notebooks have already been provided. Health care and several types of medication notebooks... I can barely keep up with medication notebooks. These should be integrated into one general notebook for a patient to fill in all kinds of health care information. The ministry should take the initiative to produce and issue such a notebook. In some cases, one patient has two or more medication notebooks." (Kashiwa area, hospital pharmacist) 